\title{
Pengaruh Umur terhadap Saat Muncul Kecambah dan Daya Kecambah Benih Kelapa Dalam (Cocos nucifera)
}

\section{(The Effect of Age on When Appeared and Viability of Tall Coconut [Cocos nucifera] Seeds)}

\author{
Alfred P. Manambangtua ${ }^{1)^{*}}$, Toni S. Hidayat ${ }^{1)}$ \\ 1) Balai Penelitian Tanaman Palma (Balit Palma), Jln. Raya Mapanget, Kotak Pos 1004, Manado, \\ 95001 \\ E-mail: alfredpahala@gmail.com
}

\begin{abstract}
At this time there is the development of coconut plantations in the community, so that the need for coconut seeds continues to increase, to meet these needs it needs to be supported by the provision of good quality coconut seeds, worth planting in the field and have the criteria for simultaneous sprouts and high viability. Results seedling seed growers by famer have an average of $80 \%$ germination with a seed age of 11 and 12 months. This study aims to determine the ideal age of seeds to be used as seeds that have germination speed and high viability. The research was conducted using two treatments consisting of coconut seeds aged 11 months and coconut seeds aged 12 months. Each treatment contained 100 plants so that 200 coconut seeds were used. The difference in age of coconut seeds gives significantly different results when they appear germination, the fastest results obtained on 12-month-old seeds. At the sprout power the highest yield was obtained for coconut seeds aged 12 months.
\end{abstract}

Keywords: coconut seeds, nurseries, seed sources

DOI: http://dx.doi.org/10.25181/jaip.v8i1.1373

Diterima: 24 September 2019 / Disetujui: 18 Februari 2020 / Diterbitkan: 15 Mei 2020

\section{PENDAHULUAN}

Kelapa (cocos nucifera) merupakan tanaman perkebunan yang memiliki peran strategis bagi kehidupan masyarakat di Indonesia, baik dari segi sosial budaya, penerimaan devisa negara, sumber pendapatan petani dan lapangan kerja yang sangat potensial (Tarigans, 2005). Seluruh bagian dari tanaman kelapa dapat dimanfaatkan, baik sebagai sumber minyak nabati, bahan baku industri pangan, bangunan, farmasi, dan oleokimia (Tenda et al., 2016) sehingga tanaman kelapa dikenal dengan tree of life.

Pengembangan tanaman kelapa saat ini harus terus diupayakan, karena kebutuhan terhadap tanaman kelapa terus meningkat baik untuk konsumsi rumah tangga maupun untuk bahan industri. Masyarakat indonesia sudah lama mengenal dan memanfaatkan kelapa. Hal ini dapat dilihat dengan penyebarannya hampir diseluruh wilayah negara kita. Pada tahun 2015 luas areal kelapa di 
Sumatera sebesar 1.142.645 ha, Jawa 818.492 ha, Nusa Tenggara dan bali 272.089 ha, Kalimantan 201,904 ha, Sulawesi 775.467 ha, Maluku dan Papua 375.002 ha (Ditjenbun, 2016).

Pada saat ini kebutuhan akan bibit kelapa terus meningkat seiring dengan pengembangan perkebunan kelapa yang ada dimasyarakat, baik untuk pembukaan lahan perkebunan kelapa yang baru, peremajaan kelapa yang sudah tua, dan menganti tanaman-tanaman kelapa yang sudah rusak akibat serangan hama dan penyakit. Untuk memenuhi kebutuhan tersebut perlu ditunjang penyediaan bibit kelapa yang bermutu baik, siap ditanam dilapangan dan memiliki kriteria kecepatan kecambah yang serentak serta memiliki daya kecambah yang tinggi (Nur \& Miftahorrachman, 2012).

Menurut Allorerung et al. (2000) untuk mendapatkan bahan tanaman atau bibit kelapa yang baik perlu dilakukan tahapan pekerjaan mulai dari penyediaan bahan tanaman, persemaian, pembibitan dan seleksi bibit. Pembibitan kelapa mempunyai peranan penting dalam keberhasilan pengembangan kelapa karena dapat menjadi indikator banyaknya produksi yang diperoleh. Dengan teknik pembibitan dan seleksi bibit yang baik produksi buah yang diinginkan dapat dicapai (Manaroinsong, Lumentut, \& Maliangkay, 2004).

Periode kritis yang sangat menentukan keberhasilan tanaman dalam mencapai pertumbuhan yang baik pada fase pembibitan adalah pertumbuhan awal bibit. Bibit yang bisa ditanam adalah : kecambah yang telah sempurna diferensiasi plumula dan radikulanya. Dan dikatakan sebagai kecambah normal jika pucuk dan akarnya dapat dibedakan dengan jelas (Astutik, Hulopi, \& Zubaidi, 2011).

Benih merupakan salah satu faktor penentu keberhasilan budidaya berbagai tanaman pertanian, termasuk tanaman perkebunan. Sebagai bahan perbanyakan tanaman, benih harus memiliki mutu yang tinggi agar dapat menghasilkan tanaman yang tumbuh baik dan berproduksi tinggi (Hayati, Pian, \& Syahril, 2011). Tingkat kematangan benih, ukuran benih, berat benih, kondisi persediaan makanan di dalam benih, embrio yang tidak sempurna merupakan faktor internal yang mempengaruhi perkecambahan benih (Ardian, 2008). Pada tanaman kelapa, petani melakukan pemanenan pada buah yang berumur 11 dan 12 bulan. Biasanya benih hasil panen ini yang dipergunakan petani sebagai sumber benih yang akan dibibitkan. Hasil benih yang bibitkan rata-rata memiliki daya kecambah $80 \%$ dan kecepatan kecambah yang lambat dan tidak seragam. Penelitian ini bertujuan untuk mengetahui umur benih ideal yang akan dijadikan bibit yang memiliki kecepatan berkecambah dan daya kecambah tinggi.

\section{METODE PENELITIAN}

Penelitian dilaksanakan di Kebun Percobaan Kima Atas, Balai Penelitian Tanaman Palma, Manado, Sulawesi Utara pada bulan Desember 2017 sampai dengan Februari 2018. Bahan-bahan yang digunakan adalah benih kelapa varietas kelapa Dalam Mapanget (DMT). Penelitian dilakukan 
menggunakan dua perlakuan yang terdiri atas : a.) benih kelapa umur 11 bulan dan b.) benih kelapa umur 12 bulan, setiap perlakuan terdapat 100 tanaman sehingga digunakan 200 benih kelapa. Peubah yang diamati adalah kecepatan berkecambah dan daya kecambah. Kecepatan kecambah diamati dengan menghitung waktu berkecambah pada masing-masing benih, selanjutnya dilakukan uji independent t-test untuk menentukan apakah terdapat perbedaan yang signifikan terhadap kedua perlakuan yang diteliti. Untuk daya kecambah dihitung dengan menggunakan rumus:

Daya kecambah $=\frac{\text { Jumlah benih berkecambah }}{\text { Jumlah benih yang dikecambahkan }} \times 100 \%$

\section{HASIL DAN PEMBAHASAN}

\section{Saat Muncul Kecambah}

Dari hasil pengamatan saat muncul kecambah, hasil uji t-test menunjukkan bahwa saat muncul kecambah benih umur 12 bulan berbeda nyata dengan benih kelapa umur 11 bulan. Saat muncul kecambah tercepat diperoleh pada umur benih kelapa 12 bulan yaitu 8,22 minggu. Hal ini diduga bahwa pada benih kelapa umur 12 bulan sudah matang secara fisiologis sehingga kandungan karbohidrat, protein dan lemak pada benih sudah siap digunakan untuk berkecambah.

Benih mencapai kemampuan tumbuh maksimum pada saat matang fisiologi. Benih yang matang fisiologis memiliki kemampuan tumbuh yang relatif lebih tinggi, sehingga menghasilkan tanaman yang lebih baik (Oktavia dan Miftahorrachman, 2012). Hasil penelitian Miftahorrachman dan Iqbal (2009) didapat bahwa benih pinang (Areca catech $u$ L.) yang matang pada umur 12 bulan memiliki kecepatan berkecambah dan daya kecambah yang lebih baik dibandingkan dengan benih yang dipanen prematur berumur 8 dan 10 bulan. Hasil penelitian pada perkecambahan Brucea javanica menunjukan bahwa semakin tua benih maka nilai awal kecambah semakin cepat (Setyowati \& Utami, 2008).

Tabel 1. Pengaruh umur benih terhadap rata-rata saat muncul kecambahan kelapa dalam

\begin{tabular}{cc}
\hline Umur benih (bulan) & Saat muncul kecambah (minggu) \\
\hline 11 & $11,76 \mathrm{a}$ \\
12 & $8,22 \mathrm{~b}$ \\
\hline Keterangan: angka yang diikuti oleh huruf yang tidak sama, berbeda nyata menurut uji t
\end{tabular}

Benih kelapa umur 11 bulan memiliki nilai rata-rata saat muncul kecambah yang terlama (11,76 minggu), hal ini dapat disebabkan karena pada saat umur 11 bulan benih belum mencapai masak fisiologis yang sempurna. Sebelum masak fisiologis, pembentukan struktur embrio dan membran belum sempurna serta akumulasi cadangan makanan dalam benih belum maksimum 
mengakibatkan vigor benih yang dihasilkan rendah, menyebabkan rendahnya saat muncul kecambah (Kartika \& Ilyas, 1994), sehingga tidak dianjurkan memakai benih umur 11 bulan atau kurang untuk tujuan perbenihan.

\section{Daya Kecambah}

Dari hasil pengamatan daya kecambah terhadap umur benih kelapa yang berbeda diperoleh bahwa daya kecambah yang tertinggi diperoleh dari benih kelapa umur 12 bulan dibanding dengan benih kelapa umur 11 bulan. Hasil tertinggi pada umur benih 12 bulan dapat disebabkan pada kondisi umur ini, buah sudah benar-benar matang secara fisiologis sehingga proses perkecambahan dapat berlangsung dengan baik.

Tabel 2. Pengaruh umur benih terhadap daya kecambah kelapa dalam

\begin{tabular}{cc}
\hline Umur benih (bulan) & Daya berkecambah $(\%)$ \\
\hline 11 & $83 \mathrm{~b}$ \\
12 & $92 \mathrm{a}$ \\
\hline Keterangan: angka yang diikuti oleh huruf yang tidak sama, berbeda nyata menurut uji t
\end{tabular}

Benih yang dipanen sebelum masak fisiologis tidak memiliki viabilitas yang tinggi, bahkan pada beberapa tanaman tidak akan berkecambah. Hal ini terjadi karena benih tersebut belum memiliki cadangan makanan yang cukup dan keadaan embrio yang belum sempurna. Sedangkan benih yang sudah masak fisiologis, telah memiliki cadangan makanan yang cukup dan embrio telah terbentuk secara sempurna (Sutopo, 2002).

Menurut Oktaviana, Ashari, \& Purnamaningsih (2016), nilai persentase daya kecambah yang tinggi akan mengindikasikan vigor kekuatan tumbuh yang tinggi dan akan menghasilkan tanaman yang homogen. Daya kecambah benih yang tinggi dipengaruhi ketersediaan cadangan makanan di dalam benih yang juga sangat menunjang proses perkecambahan benih.

Vigor bibit pada awal perkecambahan masih dipengaruhi oleh tingkat kemasakan benih karena masih menggunakan cadangan makanan dalam benih. Untuk pertumbuhan selanjutnya bibit tergantung pada unsur hara yang ada di lingkungan tumbuhnya. Benih yang memiliki vigor kekuatan tumbuh yang tinggi akan menghasilkan pertumbuhan yang baik dan sistem perakarannya mampu menyerap unsur hara yang ada di tanah tempat pertumbuhannnya (Kartika \& Ilyas, 1994). 


\section{KESIMPULAN DAN SARAN}

\section{Kesimpulan}

Umur benih kelapa Dalam yang terbaik untuk pembibitan adalah 12 bulan dengan rata-rata saat muncul kecambah 8,22 minggu dan daya kecambah $92 \%$.

\section{Saran}

Disarankan untuk penggunaan benih kelapa Dalam yang akan digunakan sebagai sumber benih pada pembibitan adalah umur 12 bulan

\section{UCAPAN TERIMA KASIH}

Ucapan terima kasih disampaikan kepada Dr. Ir. Ismail Maskromo, M.Si. selaku Kepala Balai Penelitian Tanaman Palma (Balit Palma) dan Bapak Efron Ezra Sudalangit atas dukungan dan bantuannya dalam pelaksanaan penelitian ini.

\section{DAFTAR PUSTAKA}

Ardian. (2008). Pengaruh suhu dan waktu pemanasan benih terhadap perkecambahan kopi arabika (Coppia arabica L). Jurnal Akta Agrosia, 11(1), 25-33.

Astutik., F, Hulopi \& Zubaidi, A. (2011). Penggunaan beberapa media dan pemupukan nitrigen pada pembibitan kelapa sawit. Buana Sains, 11(2), 109-188.

Allorerung, D., Amrizal, Tenda, E., Maliangkay, R. B., Hosang, M. L. A., Akuba, R. H., Bari, N. L., \& Lay, A. (2000). Petunjuk Teknis Budidaya Tanaman Kelapa (Cocos nucifera). Balai Penelitian Tanaman Kelapa dan Palma Lain. Manado

Ditjenbun. (2016). Statistik Perkebunan Indonesia 2015-2017 Kelapa. Direktorat Jenderal Perkebunan. Kementerian Pertanian.

Hayati, R., Pian, Z. A., \& Syahril, A. S. (2011). Pengauh tingkat kemasakan buah dan cara penyimpanan terhadap viabilitas dan vigor benih kakao (Thebroma cacao L.). Jurnal Floratek, 6(2), 114-123.

Kartika, E., \& Ilyas, S. (1994). Pengaruh tingkat kemasakan benih dan metode konservasi terhadap vigor benih dan vigor kacang jogo (Phaseolus vulgaris L.). Buletin Agron, 22(2): 44-59.

Manaroinsong, E., Lumentut, N., \& Maliangkay, R. B. (2004). Teknik Penyediaan Bibit Kelapa. Balai Penelitian Tanaman Kelapa dan Palma Lain. Monograf Agronomi Kelapa.

Miftahorrachman, \& Ibal, T. A. (2009). Pengaruh kematangan buah dan pengupasan sabut terhadap kecepatan kecambah, daya kecambah dan vigor bibit pinang. Buletin Palma, 36(1), 83-90.

Nur, M., \& Miftahorrachman. (2012). Pengaruh pengupasan dan jenis mulsa terhadap kecepatan berkecambah dan daya kecambah benih pinang (Arece catechu L.). Beletin Palma, 13(2), 122126. 
Oktavia, F., \& Miftahorrachman. (2012). Pengaruh lama penyimpanan terhadap kecepatan dan daya kecambah benih pinang (Areca catechu L.). Buletin Palma, 13(2), 127-130.

Oktaviana, Z., Ashari, S., \& Purnamaningsih, S. L. (2016). pengaruh perbedaan umur masak benih terhadap hasil panen tiga varietas lokal mentimun (Cucumis sativus L.). Jurnal Produksi Tanaman, 4(3), 218-223.

Setyowati, N., \& Utami, N. W. (2008). Pengaruh tingkat ketuaan buah, perlakuan perendaman dengan air dan larutan $\mathrm{GA}_{3}$ terhadap perkecambahan Brucea javanica (L.) Merr. Biodiversitas, 9(1), 13-16.

Sutopo, L. (2002). Teknologi Benih. PT Raja Grafindo Persada: Jakarta.

Tarigans, D. D. (2005). diversifikasi usaha tani kelapa sebagai upaya untuk meningkatkan pendapatan patani. Perspektif, 4(2), 71-78.

Tenda, E. T., Tulalo, M. A., Kumaunang, J., \& Maskromo, I. M. (2016). Keunggulan varietas kelapa Buol ST-1 dan potensi pengembangannya. Buletin Palma, 15(2), 93-101. 